\title{
Status of the Prevention and Control Practices of Farmers on "Bugtok" Disease in 'Cardaba' Musa balbisiana in Misamis Occidental, Philippines
}

\author{
Oliver S. Talip ${ }^{1}$, Victoria E. Matunog $^{2}$, Ricardo R. Quidato ${ }^{3}$ \\ ${ }^{1}$ College of Agriculture and Forestry, Misamis University, Ozamiz City, Philippines \\ ${ }^{2}$ Natural Science Department, Misamis University, Ozamiz City, Philippines \\ ${ }^{3}$ College of Agriculture, Mindanao State University-LanaoNorte Agricultural College, \\ Philippines \\ Corresponding email: oliver_talip@yahoo.com
}

\begin{abstract}
"Bugtok" disease in 'Cardaba' (Musa balbisiana) has become a serious problem in Philippine banana industry for the past decades. This endemic and widely distributed bacterial disease infects 'Cardaba' particularly the fruit leaving it unfit for consumption. This study aimed to identify the prevention and control practices of "Cardaba' farmers on "bugtok" disease in Misamis Occidental, Philippines using the semi-structured interview method. Results revealed that burning of suckers from infected plants, and planting of new propagules were the two most frequently practiced preventive measures. Clean culture, application of ash and cutting of infected plants were the three most frequently practiced control measures. However, findings showed that some measures, along with other less frequently used, were not appropriately and skillfully utilized. While farmers adopted prevention and control practices learned from radio or television programs, they, however, should coordinate with the Department of Agriculture for technical assistance in the context of the disease.
\end{abstract}

Key words: bacterial disease, banana, clean culture, propagules, suckers 


\section{Introduction}

Banana is an important staple food in many countries in Africa, Latin America and Southeast Asia. 'Cardaba' (Musa balbisiana) is one of the most important banana cultivars in the Philippines (Gervacio et al., 2008) and is ranked as fourth most important staple next to rice, corn and wheat (Hernandez, 2008). It is the most popular variety for processing of banana chips and crackers in the domestic and export markets (Arturo et al., 2009). It can be made into banana cue, banana fritter (turon), fried banana with flour breading (maruya), mashed (nilupak), or boiled. Some parts of the country used 'Cardaba' as a staple food in place of rice (Macabasco, 2011).

In 2004, 'Cardaba' farming flourished in Solon, Asuncion, Davao del Norte, Philippines. 'Cardaba' farmers earned a good income, which had reached as high as 56,000 to 75,000 Philippine pesos (PhP) per hectare on a per kilo farm gate price of PhP 4.00 (Nagpala, 2007). Processed 'Cardaba' or banana chips industry offers a good opportunity in the agribusiness sector in both the local and international market. Export of banana chips had been growing by $8.6 \%$ per annum on volume and $6.9 \%$ per annum on the value during the period from 1996-2005. Local consumption of 'Cardaba' also increases as youth prefers to eat healthy foods (SDCAsia, 2006).

However, "bugtok" disease threatened 'Cardaba' production since 1965 but had reached epidemic proportions in the late 80s to early 90s (Molina, 2005). "Bugtok" is a local term in Southern Philippines used to describe the discoloration and hardening of the fruit even when ripe. The disease had caused the virtual abandonment of 'Cardaba' plantations in the country (Soguilon et al., 1995). Pseudomonas solanacearum syn. Ralstonia solanacearum, a bacterium, is the causative agent of "bugtok". This is a soil-borne disease, transmitted by sucking insects feeding on infected flowers (Soguilon et al., 1995). P. solanacearum can also be transmitted mechanically through soil on tools (Molina, 2005). The main reason for "bugtok" infection is the prevalent poor management practices of banana farmers (Bacud, 2011; Fresco, 2002).

"Bugtok" epidemic hit small scale farmers in the heartland of Mindanao where banana chips industry thrived. Commercial plantation systems easily implement a rational and cost-effective disease management but not in very dispersed, numerous, small-scale farms (Molina, 2005). Soguilon et al. (1991) reported that among the five 
regions of the country, which extensively planted cooking bananas, "bugtok" affected $86.7 \%$ of the 357.3 hectares.

The province of Misamis Occidental considers banana as one of the high value crops (HVC) among those with high demand, either for fresh or processed products (Aguhob, 2012). Within this context, representative 'Cardaba' farmers from Misamis Occidental had attended seminars conducted by Mindanao Fruit Council (Minfruit Council). This is one of the business supports of USAID's Growth with Equity in Mindanao (GEM) Program, which aimed to provide trainings or technical assistance on improving productivity and the quality of 'Cardaba' (Mindanews, 2007). However, despite the technical assistance provided, there is insufficient information on the status of 'Cardaba' production in the area. "Bugtok" continued to threaten 'Cardaba' production in the Philippines as discussed during the conference hosted jointly by Asian and Australasian Plant Pathology Societies (Commodities and Futures, 2011). With this, a survey on the status of existing preventive and control measures of farmers on "bugtok" infection is necessary to revisit the existing practices and evaluate whether the Minfruit Council seminars sustained 'Cardaba' production in the area, over the years. This study determined the status of the prevention and control practices of 'Cardaba' farmers on 'bugtok' disease in Misamis Occidental, Philippines. The results of the study can be used to establish policy direction that will improve the quality and productivity of "Cardaba".

\section{Materials and Methods}

This study was conducted in sixteen study areas (3 cities and 13 municipalities), in the province of Misamis Occidental, namely: Ozamiz City, Tangub City, and Oroquieta City; municipalities of Clarin, Tudela, Sinacaban, Jimenez, Panaon, Aloran, Lopez Jaena, Plaridel, Calamba, Sapangdalaga, Baliangao, Don Victoriano, and Bonifacio (Figure 1). This study used a descriptive research design. Four "bugtok"- infected sites located within three kilometer-radius of each city or municipality were selected to represent each study area. A total of 128 randomly-selected farmers were interviewed in August 2013 about their demographic profile, the status of their 'Cardaba' (Musa balbisiana) production, and their knowledge on "bugtok" disease (Figure 2) prevention and control. Eight respondents represented each study area. A semi-structured interview was conducted with the respondents. 

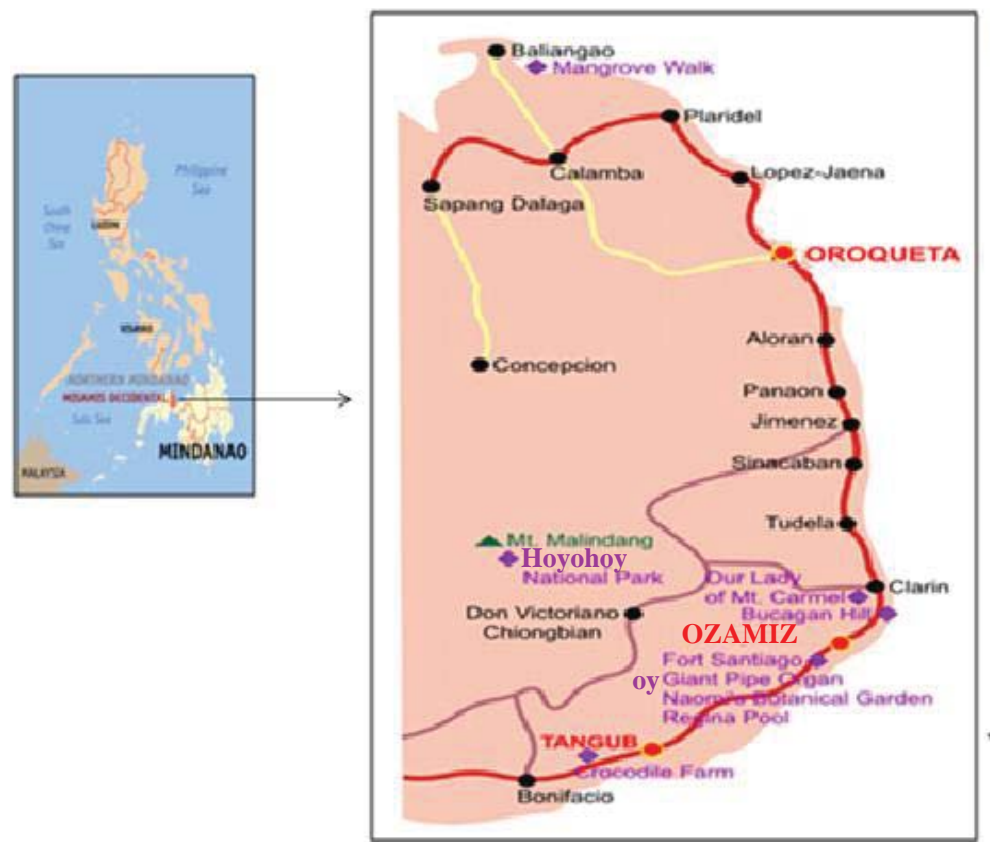

Legend

- Cities

- Municipalities

Figure 1. Location Map of Misamis Occidental showing the sixteen (16) study areas (Source: http://images.search.yahoo.com/images/view with modifications - red dots for cities; black dots for municipalities.

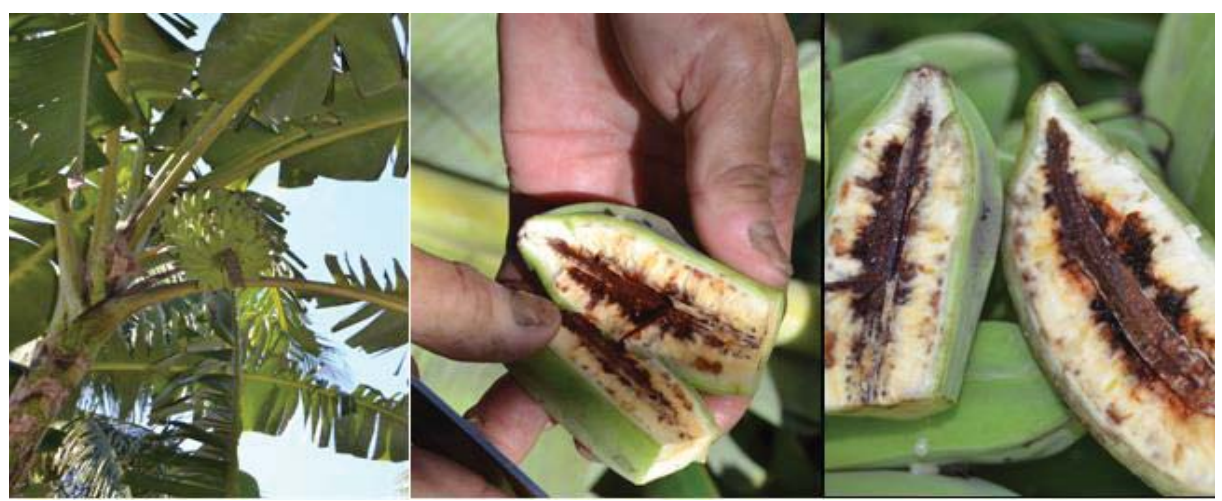

Figure 2. "Bugtok"- infected 'Cardaba'. 


\section{Results and Discussion}

Results showed that respondents practiced several control measures of "bugtok" disease (Figure 3). Few control measures practiced by the respondents were also considered as preventive measures. Most male respondents practiced clean culture. This technique involves the slashing and burning of grasses and the removal of dead and hanging leaves to remove the food source for carrier insects. Clean culture can also be considered as a preventive measure that limits the possible spread of bacterial infection. According to Pava et al. (2003), this measure prevented $97.7 \%$ of 'Cardaba' and 'Saba' from becoming infected by "bugtok" disease. Clean culture is a sanitation practice, done by the removal of dried leaves which has resulted to the reduction of a bacterial rot disease of banana (Molina, 1996).

Majority of female respondents used the application of ash as a control measure for "bugtok" disease. Wood ash, a natural pesticide was also used to control weevil in banana (Weidmann \& Kilcher, 2011). Some of the respondents practiced cutting of infected plants, replanting of new propagules, smudging to control the disease and burning of infected plants. Cutting of infected plants was commonly used to control the propagation of banana bacterial wilt (Muhangi et al., 2006). Replanting of new propagules can also be considered a preventive measure that inhibits the possible growth of infected 'Cardaba'. Smudging involves the burning of dried banana leaves, with few fresh grass leaves, to produce smoke that could drive carrier insects away. Smudging indirectly controls the spread of bacterial infection by controlling the carrier insects. Burning of infected 'Cardaba' was a control measure of "bugtok" which killed the entire infected plant.

Few respondents applied table salt to the remaining stump after the infected 'Cardaba' fruits were harvested, during early debudding, and when piercing the stalk of the infected 'Cardaba' with sharp-edged objects, such as nails or bamboo poles. The application of table salt prevented $77.9 \%$ of 'Cardaba' and 'Saba' from being infected by "bugtok" disease in the pilot demonstration of Pava (2003) using 500 grams of salt per/stump/hill. Early debudding involved the removal of male flower as soon as the hand of the fruit has formed (Vezina \& den Bergh, 2013). Debudding was a method used to control 'tibaglon' bacterial disease in cooking bananas (Molina, 1996) and banana bacterial wilt (Muhangi et al., 2006). Piercing the stalk of "bugtok" infected plant is not simply done by 
using a sharp object, instead sharp objects such as bamboo sticks (each 2.5 $\mathrm{cm}$ x15 cm) must be soaked in glyphosphate for 24 hours. This method was effective in eradicating bunchy top and bract mosaic virus-infected banana (Pava et al., 2003).

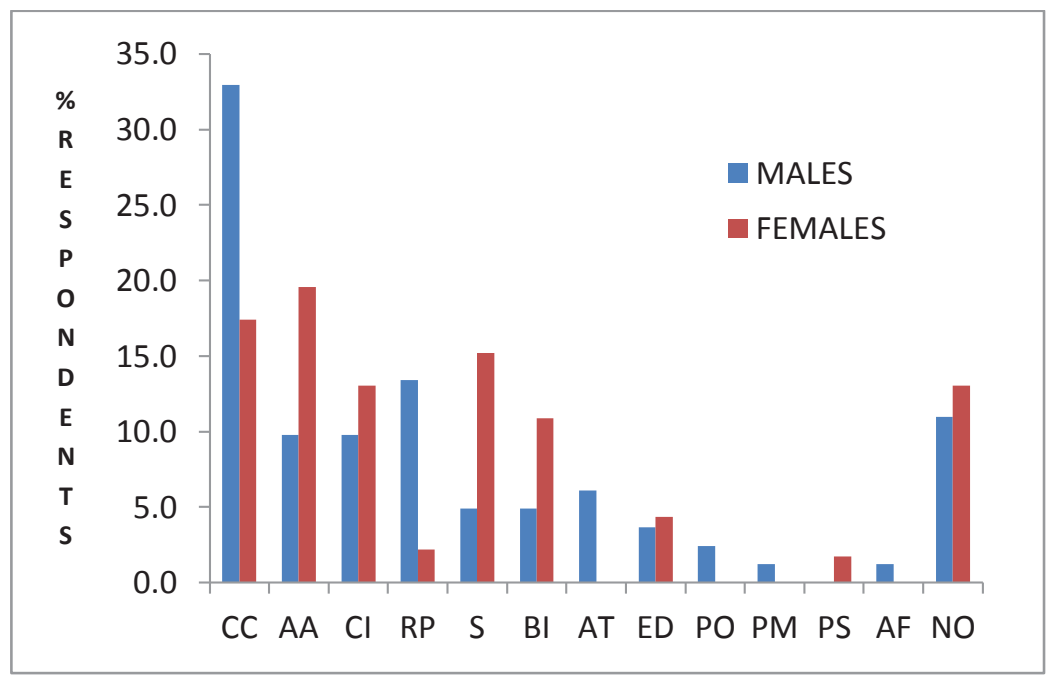

Legend: CC-clean culture; AA-application of ash; CI-cutting infected plants; RPreplanting of new propagules; S-smudging; BI-burning infected plants; AT- application of table salt; ED- early debudding; PO-piercing ofsharpedged object; PM- pouring of muriatic acid on the plant's core; PSplacing of stone on top of the cut portion;AF-application of Furadan on the cut portion; NO-no control measures practiced

Figure 3. Control measures practices on "bugtok" infection.

Some of the respondents $(<1.0 \%)$ practiced pouring of muriatic acid on the core of 'Cardaba' plant in order to kill bacterial colonies. Less than $1 \%$ of the respondents placed a stone on top of the cut portion of the 'Cardaba' plant, which could prevent the infected plant from growing continuously and a fewer number of the respondents $(<1.0 \%)$ applied a systemic insecticide Furadan ${ }^{\circledR}$ on the cut portion of the infected 'Cardaba' to control carrier insect population. However, $11.7 \%$ of the respondents did not practice any control measure as they claimed that they just left the infected 'Cardaba' unattended until the plants decomposed. Figure 4 revealed that most female farmers preferred to use burning of suckers from infected plants as preventive measures while the males preferred planting of new propagules. However, in a pilot study conducted in the northern part of Mindanao, Philippines, the three measures which 
efficiently prevent "bugtok" infection in 'Saba' and 'Cardaba' cultivars include bagging, early debudding and application of sodium chloride (table salt). The provinces of Bukidnon, Misamis Oriental and Camiguin participated in this pilot study (Pava et al., 2003). Bagging the inflorescence of 'Cardaba' immediately when it begins to bend can prevent thrips species from feeding on the flowers and transmitting the disease. Clean culture and early debudding can remove the food source for carrier insects. The application of table salt on the remaining stump adjacent to the one bearing the new flowers can destroy the bacteria where the fruits were harvested (Pava et al., 2003). Very few of both male and female respondents practiced bagging of inflorescence as a preventive measure while others claimed that they just left the infected 'Cardaba' unattended until the plants decomposed. Cutting and uprooting or rouging the mats of the banana plants suspected for the "bugtok" infection prior to planting of new propagules was a method used in controlling the banana bacterial wilt (BBW) in Uganda (Ngambeki et al., 2006).

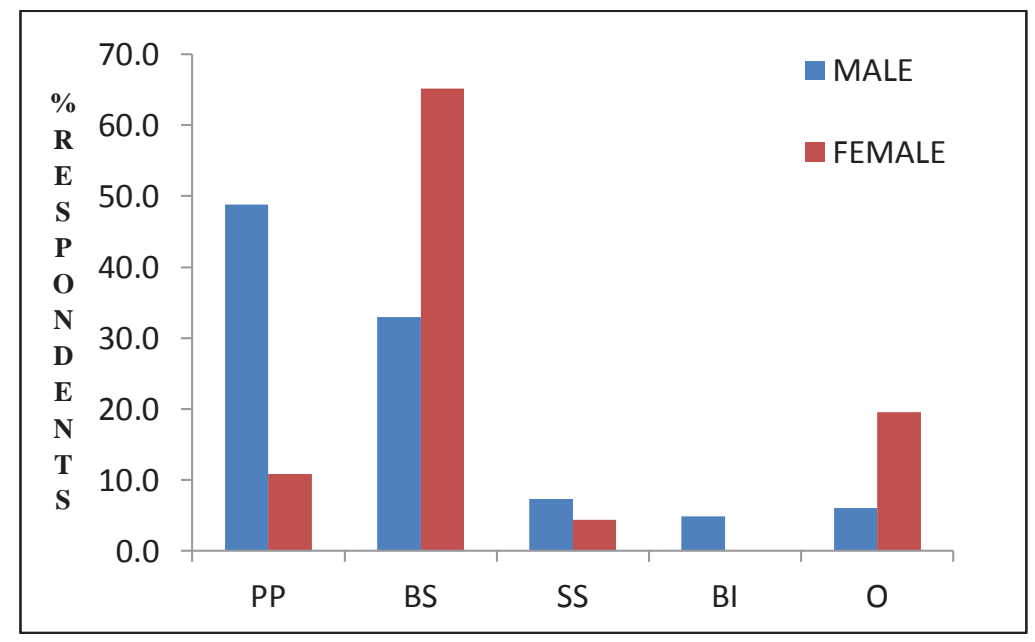

Legend: PP-planting of new propagules; BS-burning of suckers from infected plants; SS-sterilizing the soil before planting; BIbagging of inflorescence

Figure 4. Preventive measures practices of 'Cardaba' farmers 
There were many preconceived notions as to possible factors affecting the implementation of control and preventive measures however, it was noted that the current demographic shift may have an influence on the trend of implementation. Although male farmers have dominated in 'Cardaba' banana farming (64.1\%) in Misamis Occidental, there were relatively a number of female farmers $(35.9 \%)$ observed. This shift was brought about by migration of males to urban centers for better job opportunities leaving the women with the burden of managing most farm and household chores (Grand Challenges Explorations, 2013). Based on the 2002 Census of Agriculture and Fisheries (CAF), among the 4.8 million agricultural operators in the Philippines, 89 percent are males and 11 percent are females (NSO, 2009). Although, this is lower than the projection of the Food and Agriculture Organization (FAO) of the United Nations for the Least Developed Countries (LDC) for 2010, which showed $70 \%$ female participation in agriculture (FAO, 2011) still, the participation of women in 'Cardaba' farming may affect the implementation of preventive and control practices in "bugtok" infection because women farmers are often constrained in access of new farming technologies (Quisumbing \& Pandofelli, 2010). A related article shows, that in Africa, women farmers were less likely to adapt than men in terms of improved crop varieties and new management systems (Doss, 1999). Male farmers have higher access to technology than their female counterpart, this could be one of the reasons why the agriculture sector is underperforming in many developing countries because women do not have equal access to the resources and opportunities, however, they need to be more productive (FAO, 2011).

Findings showed that more respondents engaged in 'Cardaba' farming upon reaching middle adulthood than in early adulthood. The age bracket comprised of 41-70 years old constituting $86.6 \%$ among male respondents while most female respondents fall within 31-60 years old $(63.0 \%)$. At this bracket, families of the respondents had increased in size that required more finances to support growing children and aging parents (Parker \& Patten, 2013). Income augmentation becomes necessary to sustain the basic needs of the family, especially education. Hence, older adult members (61- 70 yrs. old) of the family contribute through income generation by means of 'Cardaba' farming. Their active participation could possibly affect the implementation of prevention and control measures on "bugtok" infection because they tend to choose and optimize measures they can perform well (McLaughlin \& Sprufera, 2011). 
A survey done on the educational level of the respondents placed an advantage on attaining formal education. Results showed that 'Cardaba' farmers in the area had undergone formal education. The lowest level of education was elementary level, which comprised $7.8 \%$ of the respondents; while those who graduated from college comprised $11.7 \%$ (Table 1). Respondents with the level of education ranging from high school level to college graduate comprised $64.9 \%$. Herewith, educational attainment enables the respondents to comprehend and better understand the technical information in improving 'Cardaba' farming. The farmers' ability to read, write and calculate gave them the potential to go beyond limited possibilities in enhancing their knowledge, skills and capacities to improve their livelihood (Oxenham et al., 2002). A study by Al-Rimawi (2002) also revealed that lack of the minimum education lowers the ability to comprehend and use technical information among women farmers. Thus, formal education can also be a factor.

Male and female respondents engaged in full time farming constituted $71.1 \%$, although majority $(82.8 \%$ ) had no involvement in any local or national farmers' organization. Results revealed that whatever innovations farmers made concerning 'Cardaba' farming were not directly coming from the Department of Agriculture. However, sharing the same ethnicity facilitated the diffusion of technical information in 'Cardaba' farming among the respondents. Most of the respondents are VisayanCebuano, (99.2\%) and less than $1 \%$ of the respondents are Subanen. 
Table 1. Demographic profile of 'Cardaba' farmers in Misamis Occidental.

\begin{tabular}{|c|c|c|c|}
\hline \multirow[t]{2}{*}{ Demographic Profile } & \multicolumn{3}{|c|}{ Frequency $(\%)$} \\
\hline & Male & female & Total \\
\hline Gender & $82(64.06)$ & $46(35.9)$ & $128(35.9)$ \\
\hline \multicolumn{4}{|l|}{ Age } \\
\hline $20-30$ & $2(1.6)$ & $3(2.3)$ & $5(3.9)$ \\
\hline $31-40$ & $9(7.0)$ & $14(10.9)$ & $23(17.8)$ \\
\hline $41-50$ & $24(18.8)$ & $12(9.4)$ & $36(28.1)$ \\
\hline $51-60$ & $22(17.2)$ & $10(7.8)$ & $32(25)$ \\
\hline $61-70$ & $25(19.5)$ & $7(5.5)$ & $32(25)$ \\
\hline \multicolumn{4}{|l|}{ Ethnic group } \\
\hline Visayan (Cebuano) & $82(64.1)$ & $45(35.2)$ & $127(99.2)$ \\
\hline Subanen & 0 & $1(0.8)$ & $1(0.8)$ \\
\hline \multicolumn{4}{|l|}{ Educational attainment } \\
\hline Elementary level & $6(4.7)$ & $4(3.1)$ & $10(7.8)$ \\
\hline Elementary graduate & $25(19.5)$ & $10(7.8)$ & $35(27.3)$ \\
\hline High School level & $6(4.7)$ & $6(4.7)$ & $12(9.4)$ \\
\hline High School graduate & $30(23.4)$ & $18(14.1)$ & $48(37.5)$ \\
\hline College level & $4(3.1)$ & $4(3.1)$ & $8(6.3)$ \\
\hline College graduate & $12(9.4)$ & $3(2.3)$ & $15(11.7)$ \\
\hline \multicolumn{4}{|l|}{ Number of Children } \\
\hline None & $14(10.9)$ & $4(3.1)$ & $18(14.1)$ \\
\hline 1 to 2 & $16(12.5)$ & $11(8.6)$ & $27(21.1)$ \\
\hline 3 to 4 & $25(19.5)$ & $12(9.4)$ & $35(27.3)$ \\
\hline 5 to 6 & $9(7.0)$ & $11(8.6)$ & $22(17.2)$ \\
\hline 7 to 8 & $12(9.4)$ & $6(4.7)$ & $18(14.1)$ \\
\hline 9 and above & $6(4.7)$ & $2(1.6)$ & $8(6.3)$ \\
\hline \multicolumn{4}{|l|}{ Occupation } \\
\hline Full time farmer & $68(53.1)$ & $23(18.0)$ & $91(71.1)$ \\
\hline Part-time farmer & $4(3.1)$ & $7(5.5)$ & $11(8.3)$ \\
\hline Housekeeper & 0 & $10(7.8)$ & $10(7.8)$ \\
\hline Employee & $5(3.9)$ & $3(2.3)$ & $8(6.3)$ \\
\hline Businessman & $3(2.3)$ & $2(1.6)$ & $5(3.9)$ \\
\hline Others & $3(2.3)$ & 0 & $3(2.3)$ \\
\hline \multicolumn{4}{|l|}{ Membership in Farmers' Organization } \\
\hline Farmers Association & $9(7.0)$ & $2(1.6)$ & $11(8.6)$ \\
\hline Women's Organization & 0 & $4(3.1)$ & $4(3.1)$ \\
\hline Barangay Health Worker & 0 & $1(0.8)$ & $1(0.8)$ \\
\hline None & $67(52.3)$ & $39(30.5)$ & $106(82.8)$ \\
\hline Others & $6(4.7)$ & 0 & $6(4.7)$ \\
\hline
\end{tabular}

Land ownership status of 'Cardaba' farmers (Table 2) showed that the majority of respondents $(81.3 \%)$ were owner-cultivators. However, this is lower than the NSO survey of 2002, which showed that the household members engaged in agricultural activities with their own land holdings was $86.3 \%$ (NSO, 2004). Owner-cultivators make their own decision and adopt their own method of farming without feeling the 
anxiety and uncertainty to be disposed from the land they farm (Tenaw et al., 2009). In addition, the findings revealed that $57.0 \%$ of the respondents planted 'Cardaba' to augment their income. As land owners having other sources of living, majority of the respondents did not find the urgency of seeking professional help whenever "bugtok" infection occurred. Reduction of 'Cardaba' production was not an alarming concern for respondents with other main sources of living. This study revealed that $62.5 \%$ of the respondents cultivated one half to two hectares of land and planted one to 100 suckers $(70.3 \%)$ of 'Cardaba'. Farmers procured suckers in different ways. Parents or previous landowners handed most of the suckers to $53.9 \%$ of the respondents. Relatives and friends gave suckers to $28.9 \%$ of the respondents. These results suggest that respondents spend a minimal amount or no money is spent in planting 'Cardaba'. In relation to this, $94.5 \%$ of the total number of respondents was not alarmed despite the losses incurred due to "bugtok" infection.

Table 2. Status of 'Cardaba' Musa balbisiana farming and "bugtok" disease.

\begin{tabular}{llll}
\hline \multicolumn{1}{c}{ Status } & \multicolumn{3}{l}{ Frequency $(\%)$} \\
\cline { 2 - 4 } & Male & Female & Total \\
\hline Land tenure & & & \\
Owner-cultivator & $68(82.9)$ & $36(78.3)$ & $104(81.3)$ \\
Share tenant & $13(15.9)$ & $7(15.2)$ & $20(15.6)$ \\
Leaseholder & $0(0.0)$ & $2(4.3)$ & $2(1.6)$ \\
Amortizing owner & $1(1.2)$ & 0 & $1(0.8)$ \\
Farm worker/farm labourer & 0 & $1(2.2)$ & $1(0.8)$ \\
Purpose of planting banana & & & $13(10.2)$ \\
Main source of income & $12(14.6)$ & $1(2.2)$ & $73(57)$ \\
Augment income & $40(48.8)$ & $33(71.7)$ & $42(32.8)$ \\
Home consumption & $30(36.6)$ & $12(26.1)$ & \\
Total area planted & & & $20(15.6)$ \\
Less than $1 / 2$ ha & $12(14.6)$ & $8(17.4)$ & $36(28.1)$ \\
1/2 ha to less than 1 ha & $21(25.6)$ & $15(32.6)$ & $44(34.4)$ \\
1 ha to less than 2 ha & $32(39.0)$ & $12(26.1)$ & $18(14.1)$ \\
2 ha to less than 3 ha & $10(12.2)$ & $8(17.4)$ & $8(6.3)$ \\
3 ha to less than 4 ha & $6(7.3)$ & $2(4.3)$ & $2(1.6)$ \\
4 ha and above & $1(1.2)$ & $1(2.2)$ & \\
\hline \hline
\end{tabular}


Table 2. Continued: Status of 'Cardaba' Musa balbisiana farming and "bugtok" disease.

\begin{tabular}{llll}
\hline \hline \multirow{2}{*}{ Status } & \multicolumn{3}{l}{ Frequency (\%) } \\
\cline { 2 - 4 } & Male & Female & Total \\
\hline Total no. of suckers planted & $19(23.2)$ & $14(30.4)$ & $33(25.8)$ \\
1 to 50 & $39(47.6)$ & $18(39.1)$ & $57(44.5)$ \\
51 to 100 & $16(19.5)$ & $9(19.6)$ & $25(19.5)$ \\
101 to 150 & $8(9.8)$ & $5(10.9)$ & $13(10.2)$ \\
151 and above & & & \\
No. of 'Cardaba' variety planted & $28(34.1)$ & $16(34.8)$ & $44(34.4)$ \\
1 to 50 & $36(43.9)$ & $19(41.3)$ & $55(43)$ \\
51 to 100 & $16(19.5)$ & $7(15.2)$ & $23(18)$ \\
101 to 150 & $2(2.4)$ & $4(8.7)$ & $6(4.7)$ \\
151 and above & & & \\
Procurement of suckers & $24(29.3)$ & $13(28.3)$ & $37(28.9)$ \\
Given & $11(13.4)$ & $7(15.2)$ & $18(14.1)$ \\
Purchased & $43(52.4)$ & $26(56.5)$ & $69(53.9)$ \\
Inherited & $4(4.9)$ & 0 & $4(3.1)$ \\
Others & $82(100.0)$ & $39(84.8)$ & $121(94.5)$ \\
Total no. of plants affected by "bugtok" disease & $5(10.9)$ & $5(3.9)$ \\
1 to 50 & 0 & 0 & 0 \\
51 to 100 & 0 & $2(4.3)$ & $2(1.6)$ \\
101 to 150 & 0 & & \\
151 and above & & & \\
\hline \hline
\end{tabular}

A considerable number of respondents (17\%) had been producing more than $100 \mathrm{~kg}$ /harvest of 'Cardaba' fruits before the plants were infected with "bugtok" (Figure 5). This percentage of respondents decreased during "bugtok" infection to $2.5 \%$. A higher percentage of respondents $(46 \%)$ produced a relatively lower yield $(10-50 \mathrm{~kg})$ of 'Cardaba' fruits per harvest during the time when the plants were infected with "bugtok" compared to the time when the plants were "bugtok"-free. 


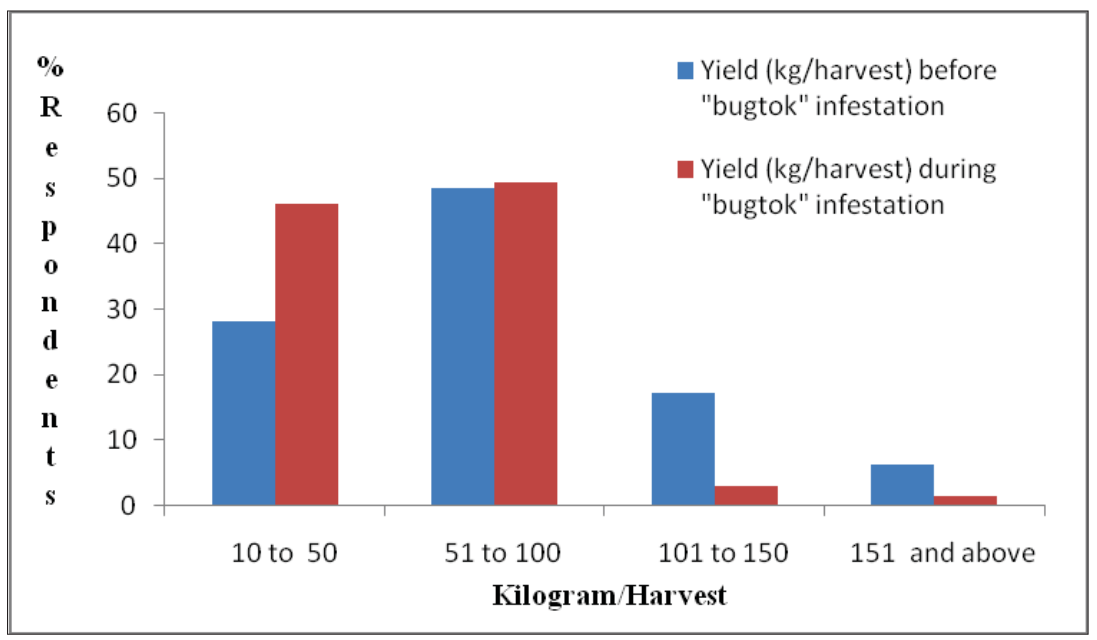

Figure 5. 'Cardaba' production (kg/harvest) before and during "bugtok" infection.

Majority of 'Cardaba' farmers did not seek or receive assistance from the Department of Agriculture in the prevention and control of "bugtok" infection, nevertheless, the respondents exhibited some measures in fighting the disease. There were many sources of information, with only $5.5 \%$ of the respondents engaged in banana farming obtained some information on the prevention and control measures of "bugtok" disease from the Department of Agriculture technicians and about 10.9\% of respondents obtained such information from their neighbors only. Majority of the respondents $(75.0 \%)$ had obtained information on prevention and control measures of "bugtok" disease from the media such as radio or television programs (Table 3). For instance, the DXIM of Cagayan de Oro City aired "Tahosa NOMCARRD (Northern Mindanao Consortium for Agriculture and Resources Research and Development)". This program discussed research results generated in the region, along with the programs and activities of the Philippine Council for Agriculture Resources Research and Development (PCARRD), through its research consortia, the NOMCARRD (Baluyos, 2010). Despite prevailing efforts, this study shows that the information dissemination through seminars, brochures, pamphlets, radio and television programs still were not properly facilitated. Such that, 'Cardaba' farmers in the area knew some measures, but the appropriate way of using them was not properly understood. 
Table 3. Sources of knowledge on "bugtok" disease

\begin{tabular}{|c|c|c|c|}
\hline \multirow[t]{2}{*}{ Status } & \multicolumn{3}{|c|}{ Frequency $(\%)$} \\
\hline & Male & Female & Total \\
\hline \multicolumn{4}{|l|}{ Number of years in banana farming } \\
\hline 1 to 2 years & $18(22.0)$ & $1(2.2)$ & $19(14.8)$ \\
\hline 3 to 4 years & $30(36.6)$ & $30(65.2)$ & $60(46.9)$ \\
\hline 5 to 6 years & $13(15.9)$ & $7(15.2)$ & $20(15.6)$ \\
\hline 7 years and above & $21(25.6)$ & $8(17.4)$ & $29(22.7)$ \\
\hline \multicolumn{4}{|c|}{ Sources of information on "bugtok" disease } \\
\hline Seminar & $6(7.3)$ & 0 & $6(4.7)$ \\
\hline Radio/television program & $59(72.0)$ & $37(80.4)$ & $96(75)$ \\
\hline Dept of Agriculture technicians & $5(6.1)$ & $2(4.3)$ & $7(5.5)$ \\
\hline Brochure, pamphlets & $3(3.7)$ & 0 & $3(2.3)$ \\
\hline Magazines & 0 & $2(4.3)$ & $2(1.6)$ \\
\hline Others & $9(11.0)$ & $5(10.9)$ & $14(10.9)$ \\
\hline \multicolumn{4}{|l|}{$\begin{array}{l}\text { Seeks technical assistance in fighting } \\
\text { "bugtok" disease }\end{array}$} \\
\hline Yes & $7(8.5)$ & 0 & $7(5.5)$ \\
\hline No & 75 (91.5) & $46(100.0)$ & $121(94.5)$ \\
\hline \multicolumn{4}{|l|}{$\begin{array}{l}\text { Receives technical assistance from the } \\
\text { Department of Agriculture }\end{array}$} \\
\hline Yes & $4(4.9)$ & $2(4.3)$ & $6(4.7)$ \\
\hline No & $78(95.1)$ & $44(95.7)$ & $122(95.3)$ \\
\hline
\end{tabular}

The export value of banana chips in the Philippines is rising by 15\% every year since 2009. The Department of Trade and Industry is promoting 'Cardaba' planting to banana farmers and has started to provide technical and financial support to 'Cardaba' farmers (Sta. Romana, 2012). Conversely, this study implied that the technical assistance has not reached the small scale 'Cardaba' farmers in Misamis Occidental thus, the technical knowledge they used to prevent and control "bugtok" infection was lacking adequacy. In this study, planting new propagules, burning of suckers of infected plants and sterilizing the soil before planting were identified as the preventive measures of 'Cardaba' farmers against "bugtok" infection. Most of the respondents in this study used clean culture, application of ash and cutting infected plants to control "bugtok" infection. However, the 'Cardaba' farmers in the Southern part of Luzon, particularly in Oriental Mindoro, implement field and mat sanitation, leaf pruning, and removal of infected plants as control measures as well as application of fungicide, insecticide and nematicide, (Bathan \& Lantican, 
2009). Although, the respondents had used control measures similar to those implemented in Oriental Mindoro, but their technical knowledge, particularly on preventive measures, needs enhancement to effectively reduced or eliminate incidence of "bugtok" infection.

\section{Conclusion and Recommendations}

Burning of suckers from infected plants, and planting of new propagules were the two most frequently practiced preventive measures of "bugtok" disease. Clean culture, application of ash and cutting of infected plants were the three most frequently practiced control measures of the disease. Clean culture and replanting of new suckers practiced by the respondents as control measures were also considered preventive measures that limit the possible spread and growth of infected 'Cardaba'.

It was noted that farmers in the area lack the motivation to maximize 'Cardaba' production, such that, they were not keen enough in seeking technical assistance from the Department of Agriculture. Land ownership and having an alternative source of income can be a factor accounting for the low 'Cardaba' production in Misamis Occidental. Owners do not typically aspire for large scale production because the minimal farm input in 'Cardaba' farming did not require a return of their investment.

'Cardaba' farmers prevent and control "bugtok" disease by adopting measures which they learned from radio or television programs. However, it was observed that some measures, along with other less frequently used, were not appropriately and technologically utilized. To maximize production, small scale 'Cardaba' farmers should be properly guided by the Department of Agriculture. Seminars and trainings should be conducted regularly, and assistance in all forms should be provided to implement appropriateness in using prevention and control measures to help eradicate "bugtok" disease or to meet the high standards required by the market. Women 'Cardaba' farmers should also be recognized and be given access to technology and incentives that were received by their male counterparts. Small scale 'Cardaba' farmers, when properly assisted, can become assets who can be utilized to improve agribusiness in the area and help bring the people of Misamis Occidental to economic stability. 


\section{Acknowledgment}

Authors are grateful to Misamis University for funding this study and the alumni of the College of Agriculture for the support during fieldwork. The personnel of the Department of Agriculture in the respective areas are also acknowledged for providing invaluable assistance in facilitating the interview.

\section{Literature Cited}

Aguhob, R. C. (2012). Banana Industry Stakeholders' Forum in Kamayan sa Oro. Philippine Information Agency-10. Retrieved from http://pia10.blogspot.com/2012_07_08_archive.html

Al-Rimawi, A. S. (2002). The role of Jordanian women farmers in livestock production with implications to agricultural extension education. Journal of International Agricultural and Extension Education, 9(1).

Arturo, A. S., Nuevo, P. A., Eusebio, J. E. \& Burgos, B. M. (2009). Analysis for banana processing businesses and their support environment. Philippine Council for Agriculture, Forestry and Natural Resources Research and Development (PCARRD-DOST). Retrieved from http://platforms.inibap.org/processing

Bacud, D. C. (2011). Supply Chain Improvement for the Banana (Saba) Industry in Cagayan Valley. ISU-Cabagan Journal of Research, 20(1). Retrieved from http:// ejournals. ph/ index.php? journal= ISUCJR

Baluyos, T. S. (2010). Reaching out people through radio. Department of Science and Technology Regional Office. Sunstar Cagayan de Oro. Retrieved from http://www.sunstar.com.ph/cagayan-de-oro/reachingout-people-through-radio

Bathan, B. M., \& Lantican, F. A. (2009). Factors affecting yield performance of banana farms in Oriental Mindoro, Philippines. Journal of ISSAAS [International Society for Southeast Asian Agricultural Sciences], 15. 
Commodities and Futures. (2011). Australia report says bacteria hit banana farms abroad. International Business Times. Retrieved from: http://au.ibtimes.com/articles/138647/20110428/australia-report

Doss, C. (1999). Twenty-five years of research on women farmers in Africa: Lessons and implications for agricultural research institutions; with an Annotated Bibliography. CIMMYT Economics Program Paper No. 99-02.

FAO (Food and Agriculture Organization of the United Nations). (2011). The state of food and agriculture. Retrieved from http:// www.fao. org/docrep/013/ i2050e/ i2050e.pdf

Fresco, M. C. O. (2002). Combating the banana bugtok disease effectively. BAR Chronicle, 3.

Grand Challenges Explorations. (2013). Labor saving strategies and innovations for women smallholder farmers. Global Challenges in Global Health. Retrieved from http:// www. grandchallenges.org/ Explorations/ Topics/ Pages/ WomenSmallholderFarmersRound11. $\operatorname{aspx}$

Gervacio, D. D., Dawi, N. M., Fabregar, E. G., Molina, A. B., \& Bergh, I. (2008). Agronomic performance of selected local and introduced banana cultivars (Musa spp.) under commercial management practices in Davao, Philippines. Philippine Journal of Crop Science, 33(3), 7181.

Hernandez, M. E. E. (2008). Sweet crunchy bite for the banana chips industry [Southwestern Mindanao, Philippines]. BAR Research and Development Digest, 10.

Macabasco, D. R. (2011). A Situationer on Philippine Bananas. Food and Agri Business Monitor. University of Asia and the Pacific's Center for Food and Agri Business, Pasig City Philippines. Retrieved from http://www.ats-sea.agr.gc.ca/ase/5985-eng.htm

Map of Misamis Occidental. Retrieved from http://images.search.yahoo. com/images/view 
McLaughlin, A. C., \& Sprufera, J. F. (2011). Aging farmers are at high risk for injuries and fatalities. NC Med J, 72(6), 481-483.

Mindanews. (2007). Banana chips: Bridging the gap. Greatworld International Management Inc. Retrieved from http:// www. mindanews.com/c11- business/2007/06/21/banana-chips- bridgingthe-gap/

Molina, G. C. (1996). Integrated management of 'Tibaglon', a bacterial fruit rot disease of cooking bananas under farmer's field. Philippine Phytopathology, 32, 83-91.

Molina, A. B. (2005). Managing bacterial wilt/fruit rot disease of banana in Southeast Asia. Proceedings of the workshop held in Kuala, Uganda, 14-18 Feb. 2005. Retrieved from http://ibap. org/ fusarium_ wilt/ images/ stories/ file/ developing_regional_strategy_ Molina.pdf

Muhangi, J., Nankinga, C., Tushemereirwe, W., Rutherford, M., Ragama, P., Nowakunda, K., \& Abeyasekera, S. (2006). Impact of awareness campaigns for banana bacterial wilt control in Uganda. African Crop Science Journal, 14(2), 175-183.

Nagpala, E. G. E. (2007). Cultivating success with 'Cardaba'. BAR (Bureau of Argricultural Research) Chronicle, 8(9).

National Statistics Office (NSO). (2004). A Review of the Agriculture Sector in Central Visayas. Retrieved from http://www.census.ph. content/ review-agriculture-sector-central-visayas

National Statistics Office (NSO). (2009). Women in agriculture. Retrieved from http://www.census.gov.ph/content/women-agriculture

Ngambeki, D. S., Tushemereirwe, W., \& Okaasai, O. (2006). Awareness of banana bacterial wilt control in Uganda: 2. Community Leader's perspective. African Crop Science Journal, 14(2), 165-173. 
Oxenham, J., Diallo, A. H., Katahoire, A. R., Petkova-Mwangi, A., \& Sall, O. (2002). Skills and Literacy training for better livelihoods: A review of approaches and experiences. The World Bank, Human Development Sector Africa Region. Retrieved from http://www.glp.net/c/document_library/get_file?folderId=12858\&nam $\mathrm{e}=\mathrm{DLFE}-. \mathrm{pdf}$

Parker, K., \& Patten, E. (2013). The sandwich generation: Rising financial burdens for middle-aged Americans. Pew Research Center, Retrieved from http:// www.pewsocialtrends.org/2013/01/30/the-sandwich generation

Pava, H. M., Franje, N. S., \& Timario, T. J. (2003). Banana pilot demonstration studies for Bukidnon: Table salt \& early debudding to control 'bugtok' disease of cooking banana cultivars' Saba' \& 'Cardaba'. Philippine Journal of Crop Science, 28(2), 31-43.

Quisumbing, A. R., \& Pandolfelli, L. (2010). Promising approaches to address the needs of poor female farmers: Resources, constraints, and interventions. World Development, 38(4), 581-592.

Sta. Romana, J. J. (2012). PHL banana industry pins hope on chips for revenue. GMA News online. Retrieved from http://www.gma network.com/news/story/281947/economy/agricultureandmining

Soguilon, C. E., Magnaye, L. V., \& Del Valle, R. A. (1991). 'Bugtok' or 'tibagnol' disease of cooking bananas. Philippine Journal of Crop Science, 16.

Soguilon, C. E., Magnayeo, L. V., \& Natural, M. P., (1995). "Bugtok" Disease of Banana. Musa Disease Fact Sheet No. 6. International Network for the Improvement of Banana and Plantain (INIBAP). Retrieved from http:// www. bioversityinternational. org/ Bugtok_of_ banana_uploads/tx_news/ of_banana_701.pdf 
Strategic Development Cooperation Asia (SDCAsia). (2006). Philippines processed banana value chain analysis. Retrieved from http://www.value-chains.org/dyn/bds/docs/detailold/610/1

Tenaw, S., Zahidul Islam, K. M., \& Parviainen, T. (2009). Effects of land tenure and property rights on agricultural productivity in Ethiopia, Namibia and Bangladesh. Retrieved from http:// www.fao.org/ fileadmin/ user_upload/fsn/docs/HLPE/Discussion_Paper_33.pdf

Vézina, A., \& den Bergh, I. V. (2013). Xanthomonas wilt. ProMusa. Retrieved from http://www.promusa.org/tiki-index.php? page= Xanthomonas+wilt

Weidmann, G., \& Kilcher, L. (Eds.) (2011). African organic agriculture training manual. Frick, Switzerland: Research Institute of Organic Agriculture (FiBL). 